\title{
AN INTERDISCIPLINARY APPROACH TO THE PRESERVATION OF THE GAIOLA ARCHAEOLOGICAL UNDERWATER PARK AND THE POSILLIPO COASTLINE, BAY OF NAPLES (SOUTHERN ITALY)
}

\author{
M. Simeone a, C. De Vivo b, P. Masucci a
}

a Centro Studi Interdisciplinari Gaiola onlus, 27/28 Discesa Gaiola, 80123, Napoli Italy - info@gaiola.org

b IMT Institute for Advanced Studies, Lucca, 6 Piazza S. Ponziano, 55100 Lucca Italy- caterina.devivo@imtlucca.it

KEY WORDS: Underwater archaeology, Management plan, Data popularization, Marine Protected Area, Bay of Naples

\section{ABSTRACT:}

The aim of this paper is to present ten years of underwater archaeology investigations in the Marine Protected Area "Gaiola Underwater Park" in Naples, Southern Italy since its institution in 2002. These results are at the basis of a development plan that is now the starting point for new research aimed to create a model of enhancement for the underwater archaeological heritage in the Mediterranean context. The project is developed by an interdisciplinary group of young researchers so that all the issues correlated with the marine environment can be taken into account.

\section{INTRODUCTION}

The Marine Protected Area "Gaiola Underwater Park" formally came into being with the interdepartmental ministerial order signed by the Italian Government in 7/8/2002. The Underwater Park takes its name from the two small islands a few meters off the Posillipo coastline in the Western part of the Bay of Naples, in Southern Italy. The local governmental authority in charge of the management of the area is the "Soprintendenza Speciale per i Beni Archeologici di Napoli e Pompei". With its 41,6 hectares this Marine Protected Area (MPA) is the smallest in Italy and is unique not only for its archaeological and historical heritage but also its environmental riches (Simeone \& Russo, 2005). It is divided into "Integral Reserve Area" (A Zone), which is under a strict preservation order, and a "General Reserve Area" (B Zone) where there are fewer restriction (Figure 1). Together with the Pausilypon archaeological $\operatorname{Park}^{1}$ this MPA is a naturalistic and archaeological treasure and that is why it is so important to protect it.

The Posillipo coastline is in fact the only stretch of coastline for more or less $50 \mathrm{~km}$ (from the town of Castellammare to the town of Pozzuoli), which has preserved its original environment, while all around the landscape has been completely destroyed by decades of violent urbanization and industrialization. To preserve the area and its cultural heritage has been and is extremely problematic, the main reason being the Park's difficult social and territorial background which affects it negatively due to the continuous and extreme anthropic pressure via both land and sea. Unfortunately, this problem is exacerbated by the lack of a adeguate policy of management of the coastline. The aim of this paper is to explain how in the last ten years, a collaboration between the Soprintendenza Speciale per i Beni Archeologici di Napoli e Pompei and the Centro Studi Interdisciplinari Gaiola onlus (CSI Gaiola), a local NGO active on the territory, initiated an important development and preservation process of this incredible area, demonstrating the significant role of scientific

\footnotetext{
${ }^{1}$ This paper will mainly focus on the problems connected with the management of the MPA "Gaiola Underwater Park"; but because the two are strictly connected it is important to at least mention the Pausilypon Archaeological Park.
}

research and the use of technological instruments such as GIS and underwater surveys to obtain these results.

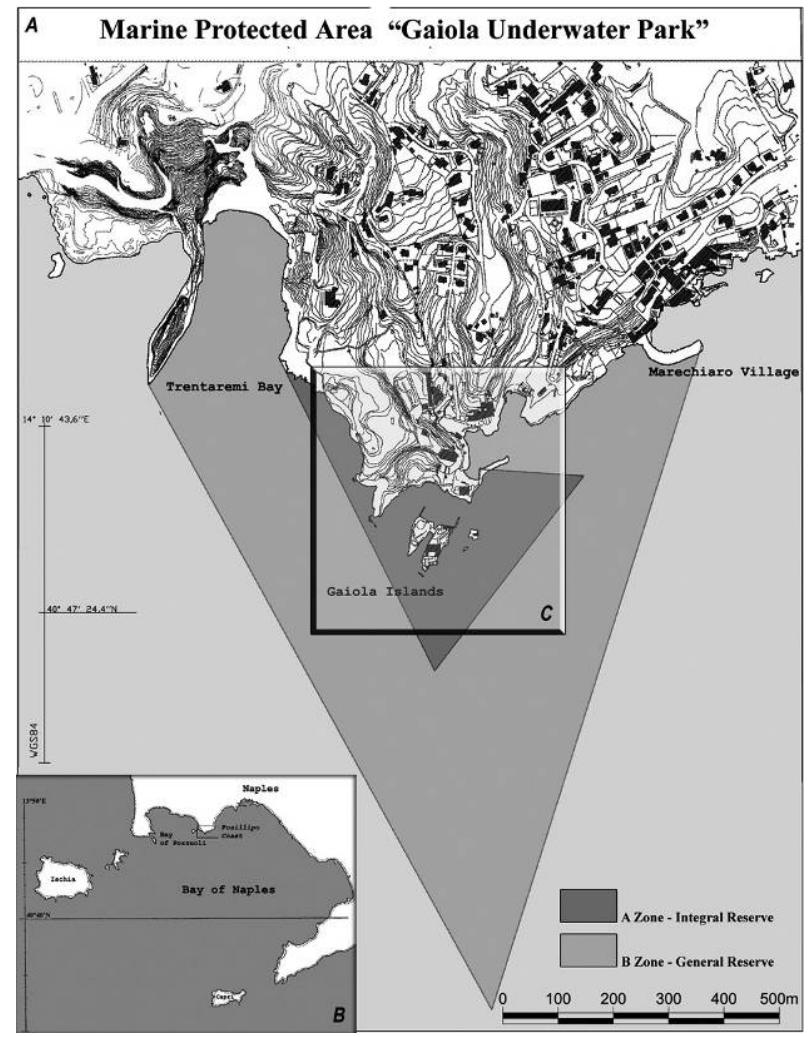

Figure 1 A) Studied area: MPA "Gaiola Underwater Park"; B) Location of Posillipo Coastline in the Bay of Naples; C) Location of Studied Sub-Area.

\subsection{The Archaeological Context}

The hill of Posillipo encloses the Bay of Naples to the northwest, separating it from the Bay of Pozzuoli and acting as a breakwater between the western and the eastern sectors of the city of Naples. Geologically it is part of the volcanic system of the Phlegrean Fields representing the eastern edge of the caldera 
that formed following the Neapolitan Yellow Tuff eruption (15 ka: Deino et al., 2004). From the geo-morphological viewpoint the coastal sector, which is almost entirely rocky, presents a marked contrast between the western stretch of the Gaiola Islets (from which the MPA takes its name) characterized by the high cliffs (up to $150 \mathrm{~m}$. above the sea level, where the Pausilypon Archaeological Park is situated), and the eastern stretch where the hillside gently slopes towards the sea. Since the $1^{\text {st }}$ century B.C. this latter coastal tract has been densely inhabited, as witnessed by the numerous Roman remains to be seen along the coastline both above and below the surface of the sea. The name of the hill itself derives from the Roman villa of Pausilypon (an ancient Greek word which meant "place where all sorrow ends"), the remains of which have been identified in the area extending from the Trentaremi promontory to the area of Marechiaro. The villa was built by the Roman Equestrian knight Publius Vedio Pollio in the $1^{\text {st }}$ century B.C., on whose death (15 B.C.) under the reign of the Emperor Augustus, it became part of the imperial estate (Vecchio, 1999). This villa, which underwent modifications and extensions throughout the centuries, is one of the most typical examples of the seaside properties of the Roman elite at the end of the Republican Age; at that time for the Equestrian class it became common to build luxurious villas by the sea and enriching them with private harbours and fishponds (Rustico, 1999). The remains of the Pausilypon villa are now technically divided between two archaeological areas: The Pausilypon Archaeological Park (on land) and the Gaiola Underwater Park (submerged in the sea). Both Parks are under the authority of the Soprintendenza Speciale per i Beni Archeologici di Napoli e Pompei, but are run by two different departments; in both areas the Soprintendenza is helped by the CSI Gaiola in the preservation, organization and enhancement of the sites and in the research activities. Nowadays the remains of this important seaside villa lie partially underwater because of ground movement and the consequent subsiding of the original coastline due to volcanictectonic activity (Günther, 1903; Simeone \& Masucci, 2009).

In fact, geologically, the Posillipo hillside is a part of the Phlegrean Fields Volcanic System, because it forms the Eastern border of a caldera which originated after the so-called Neapolitan Yellow Tuff Eruption (Deino et al., 2004). All this area of the Phlegrean Fields is affected by the volcanic-tectonic phenomenon called bradisism (from ancient Greek = slow movements) ground movement which causes the ground to subside or rise. For this reason in the Gaiola area many parts of the Pausilypon villa, in particular those structures that in Roman times were built very close to the sea, lie underwater. In the A zone of the MPA approximately $56 \%$ of the seabed is noticeably characterized by a hard tuff substratum and it is clear that almost all the hard substratum was radically disturbed by excavation work carried out in the Roman times for the construction of landing stages, communication trenches and coastal buildings, but especially for fishponds and the channelsystem necessary for changing the fishpond water. The most interesting archaeological features of the area are: the private harbour built with the opus pilarum technique, an artificial canal, a nymphaeum, coastal cavities and the fishpond for the breeding of moray eels (Simeone \& Masucci, 2009; Simeone et al., 2008; Simeone et al., 2010).

Thanks to the presence of this incredibly rich underwater archaeological heritage it has been possible to estimate the relative sea-level variation in this area (Simeone \& Masucci, 2009). Unfortunately this huge heritage was completely abandoned for decades (Caputo, 2004), and before the institution of the Park in 2002 it was not preserved in any way. The others remains of the Pausilypon villa found in the Pausilypon Archaeological Park there is what is left of a theatre that had a seating capacity of 2000 people, a small Odeion and the impressive Seiano Tunnel (a passage of $770 \mathrm{~m}$. long and with a maximum height of $14 \mathrm{~m}$. dug out in the Posillipo hillside).

It also has to be said, that even after the Park was formally established ten years ago, serious problems had to be solved in order to protect and develop these remains, because of their difficult social and territorial context. In fact, the Park is in one of the few areas in Naples where people have access to the sea and so can go swimming or boating for free (there are lidos in Naples but they are expensive), and for this reason the park is exposed to great anthropic pressure.

At this point it might be interesting to consider some of the results which ten years of activity in the Park have brought about, also thanks to a new but growing interest in this archaeological area and the new discoveries that have been made possible by instruments and methods like the GIS and the underwater archaeological survey.

\section{NEW SURVEYS AND TECHNOLOGY}

The Posillipo hillside Roman villa was included in the Phlegrean Fields residential system, where all the Roman aristocracy had property and sea-side villas for otium (D'Arms, 2003); but unlike the rest of the Phlegeran Coast (Pozzuoli, Baia, Bacoli, Miseno), where specific studies have been carried out not only from purely archaeological but also from the geoarchaeological viewpoints, research into the Posillipo coastline still mostly refers back to R.T. Günther's excellent work dated 1903. In Günther's work not only the surveying and the mapping of the submerged archaeological structures along the coast were carried out for the very first time, but, on the basis of his findings, an estimation of the relative sea-level variation (RSLV) was also made (Günther, 1903, 1913); an evaluation subsequently reviewed first by L. Jacono in 1913 and then by M. Pagano in 1981, whose work is mainly based on the interpretation of aerial photographs. In 2006 the Centro Studi Interdisciplinari Gaiola Onlus began to implement the knowledge on the Gaiola underwater heritage and the RSLV in the area through new surveys, also because, naturally, the previous research in the area was limited by the fact that when it was realized it was impossible to scuba dive. Thanks to these studies a new geo-referenced map of the underwater archaeological structures and of the many coastal cavities has been created and, new hypotheses on the RSLV on the Posillipo coastline since Roman times have been formulated (Figure 2). In this way it has also been possible to give some explanation to the present coastal geo-morphology of the area, enhancing not only the archaeological of the area, but also the environmentalgeological value of the area. The first study phase was aimed towards the elaboration (through CAD software) of a detailed geo-referenced map of the submerged structures. Data acquisition was carried out in free diving (without underwater breathing apparatus) through visual census transects, with widerange observation, planned on the basis of aerial photograph analysis, followed by detailed surveys of the structures listed below, and carried out by using underwater breathing apparatus. The surveys were made on the submerged archaeological structures and generally all the conspicuous geo-morphological elements ascribable to the anthropic reorganization of the tuff substratum or to sea erosion (wave cut notches, abrasion platforms, etc.). 


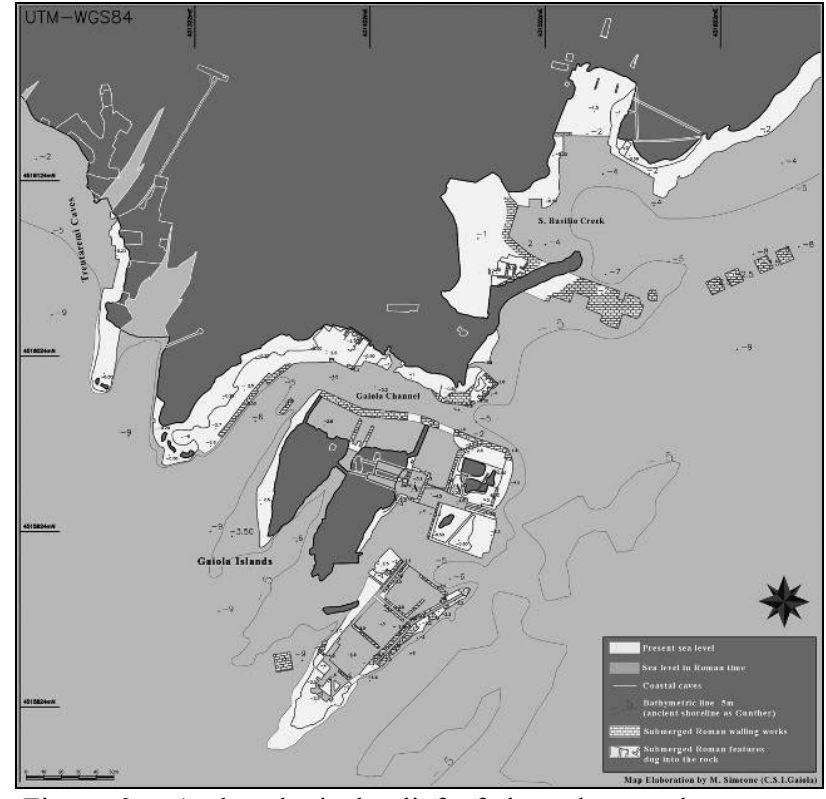

Figure 2 - Archaeological relief of the submerged structures and coastal caves in the studied Sub-Area, with indication of current sea level and estimated Roman sea level. (Map Elaboration by M. Simeone-C.S.I.Gaiola® )

At the same time, a census was made by carrying out the detailed planimetric survey of the cavities considered most significant from the historical and geo-morphological point of view.

In the second part of the study the archaeological and geomorphological data were combined, and then some hypotheses on the use of the underwater structures and on the reconstruction of the coastline as it looked in Roman times were made. As regards the use of archaeological data in the calculation of the RSLV in the last 2000 years, it was possible to refer to some markers such as cavities, landfalls and then above all the fishponds. The importance of the Roman fishponds in studies of this kind in the Mediterranean Area has been recognized by various authors (Schmiedt, 1972; Pirazzoli, 1976; Lambeck et al., 2004; Anzidei et al. 2005; Marriner \& Morhange, 2007).

The reliefs were realized by using a pole with a metric graduation for all the structures lying at a maximum depth of 2 $\mathrm{m}$., and by using depth gauges for structures lying at a greater depth. To map the structures lying more than $10 \mathrm{~m}$. from the coastline a portable GPS was used. At the same time, during the data acquisition using GPS, reliefs on land were made with a survey compass and using the position of some known points on land as reference. All the acquired data was standardized by analysing tide gauge and meteorological data, in order to make uniform the sea level heights. All the data acquiring campaigns were recorded on camera and documented by videoing.

This campaign demonstrated the great historical/archaeological and environmental/geological relevance of the Gaiola Marine Protected Area. The new reliefs made a new, detailed view of the area's archaeological system possible, and, at the same time, the structures, especially the moray eel fishponds, were fundamental to calculating the RSLV (Figures 2-3). In fact, thanks to a $1^{\text {st }}$ century B.C. Latin treatise on how to construct a fishpond according to the seabed and the fish you needed to breed (Columella, De Re Rustica, Liber VIII), it is possible to estimate which part of the fish pond was supposed to be underwater and which not in Roman times. The data acquired in the moray eel fishponds show that the sea level in Roman times was at least $3 \mathrm{~m}$. lower than it is now (the estimation takes into consideration not only the local effect of the bradisism, but also global changes in sea level variation) (Simeone \& Masucci, 2009).

The complexity of the area is also of great interest since it is the result of anthropic modifications of the tuff substratum, volcanic-tectonic movement and marine erosion. At present further investigation are being carried out in the area to acquire new elements that could lead to a deeper understanding of the Posillipo coastline archaeology, history, environment and geoarchaeology .

These studies and this research were and still are the basis for the development of a protection strategy for the area, as before developing a plan detailed information on the MPA seabed was, of course, necessary. For this reason, it is important to remember that not only an archaeological analysis, but also environmental investigations have been carried out on the area to study the sea life of the MPA seabed and to learn whether the institution of the Underwater Park is having a positive impact on the environment.

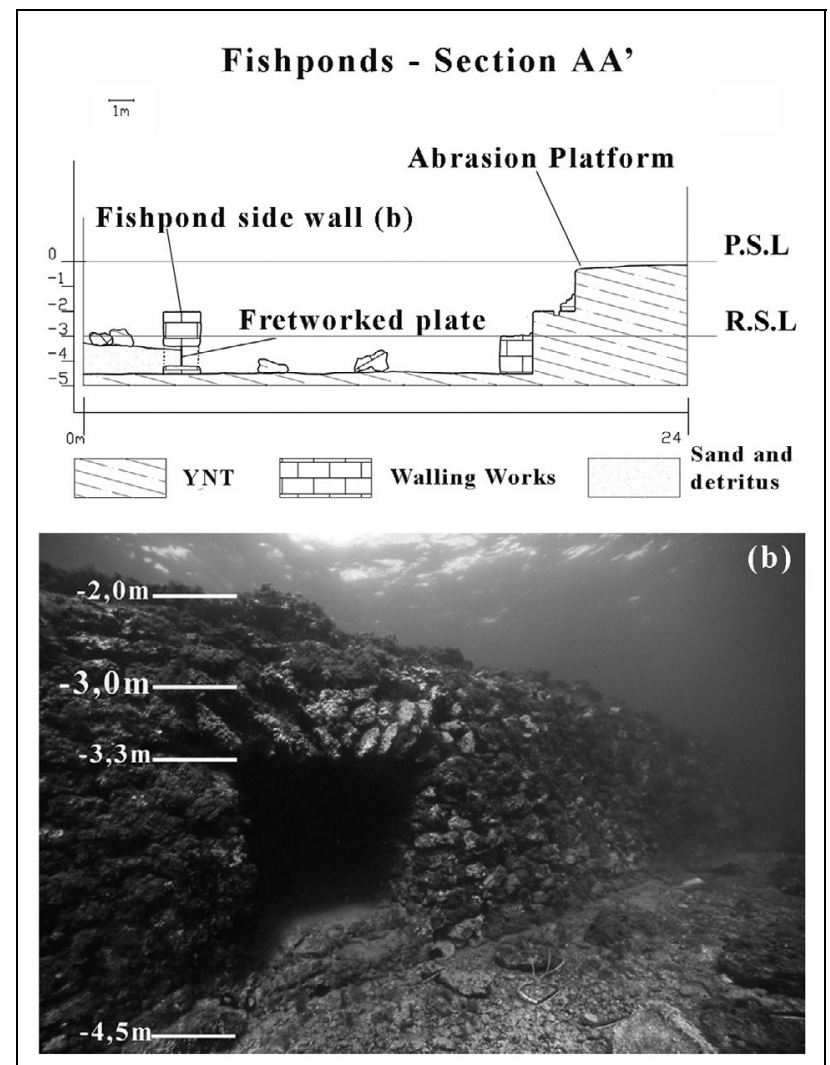

Figure 3 - Sections indicated in Figure 2, with indication of current sea level and estimated Roman sea level. b) side wall of hypogean fishponds, with indication of significant heights. (Photo G. Villani(C)

\section{THE PRESERVATION AND DEVELOPMENT PLAN}

The Marine Protected Area "Gaiola Underwater Park" was formally established in 2002, by an Interdepartmental ministerial order signed by the the Italian Ministry for the Environment, and the governmental authority in charge is the Soprintendenza Speciale per i Beni Archeologici di Napoli e Pompei. In 2005 the Soprintendenza stipulated an agreement with the Centro Studi Interdisciplinari Gaiola Onlus (Interdisciplinary Studies Centre Gaiola: CSI Gaiola), an NGO active on the area since 2004, for the protection and the enhancement of the area. The NGO was created in 2004, as the 
result of a research project on integrated coastal zonemanagement of the Posillipo coastline developed in the Department of Enviromental Sciences of the Università degli Studi di Napoli "Parthenope", and composed of a group of young researchers and volunteers with different specialization backgrounds, so that the management and the study of the various features of the area could be guaranteed: archaeologists, cultural heritage managers, biologists, marine biologists, natural scientists and scuba divers. The strong collaboration between the manager authority (Soprintendenza) and the CSI Gaiola made possible in 2005 the development of an operative plan for the protection of the Underwater Park.

Thanks to the data acquired through the research conducted, it has been possible to analyze on the quality and the risk markers that impact the Underwater Park (Table 1). On the basis of this analysis a methodological approach has been developed (Figure 4); the principle is to strictly correlate the research and the dissemination activities.

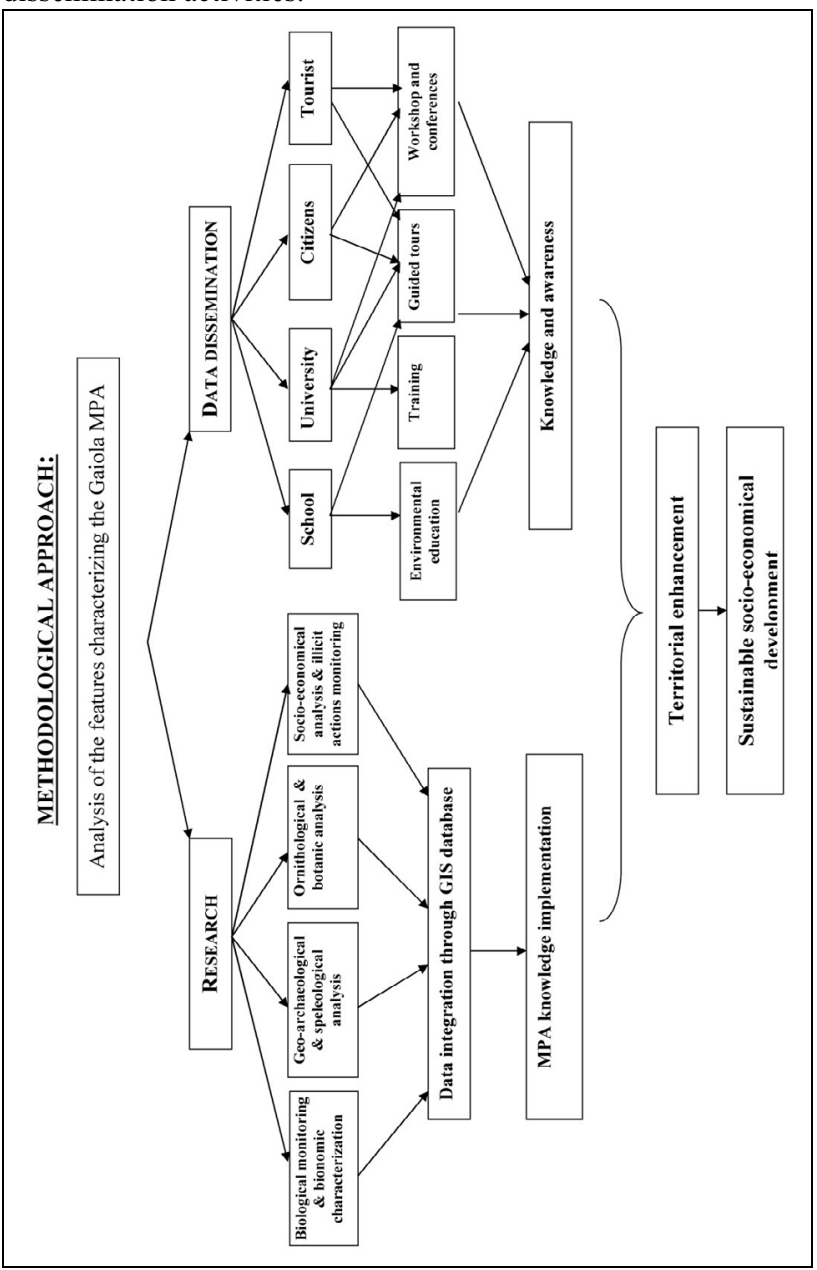

Figure 4 CSI Gaiola Methodological approach to the management of the MPA "Gaiola Underwater Park".

The approach tries to be as interdisciplinary as possible, covering all the fields that need to be analyzed in such a particular environment through different specialization collaboration-groups formed of members of the NGO staff. The aim of the plan is to create sustainable development through two parallel work programmes. On the one hand, there is the scientific research which is needed to acquire knowledge and a deeper understanding of the historical, archaeological and environmental resources of the MPA, and at the same time these resources constitute the focal point on which the protection work programme focuses. On the other hand, an intense data- popularization programme is carried out to increase the local population's awareness of the importance of the area. Learning about the cultural and environmental heritage, and then to appreciate it, may eventually lead to a greater sense of belonging to a place which in turn may lead to a greater sense of responsibility for this heritage and to the sharing of the resources in a sustainable way. This has to involve the participation of all age groups, the new and older generations. The awareness campaigns take place in the MPA and in the Pausilypon Archaeological Park (where the archaeological remains that did not sink are preserved) that in this way become open air workshops where it is possible to observe and feel the close relationship that has always existed between the sea and human beings. Since 2006 several guided itineraries have been created and organized in the Gaiola Underwater Park and the Pausilypon Archaeological Park to allow people to discover the environmental and historical heritage of the sites; the guides are all experts on the area, but the most important thing is that guided tours had never been organized before in this area, and more surprising, many local people did not even known that these area existed. The guided tours are both on land, in the Pausilypon Archaeological Park, and on water in the MPA (by boat, snorkelling and diving); integrated itineraries are also organized.

As far as the data dissemination is concerned however, the most important project developed is the "Sea of Naples" which is an environmental education project for schools and universities. The aim is to guide the new generations towards knowledge and respect of the sea, both from a cultural and naturalistic point of view, through lessons, workshops and games.

\begin{tabular}{|c|c|}
\hline Quality markers & Risk markers \\
\hline $\begin{array}{c}\text { - Underwater and partially } \\
\text { underwater archaeological } \\
\text { structures (I century B.C) }\end{array}$ & - Territorial and social context \\
\hline $\begin{array}{c}\text { - Great variety in the geo- } \\
\text { morphological composition of } \\
\text { the seabed }\end{array}$ & $\begin{array}{c}\text { - Extreme anthropic pressure, } \\
\text { especially during spring/summer, } \\
\text { due to the sea bathing and the } \\
\text { yachting }\end{array}$ \\
\hline $\begin{array}{c}\text { - Highly differentiated sea-life } \\
\text { - Bad management of the } \\
\text { bathers inside the Marine } \\
\text { Protected Area }\end{array}$ \\
\hline $\begin{array}{c}\text { - Presence of relevant } \\
\text { biocenosis, protected species } \\
\text { and characterizing habitat }\end{array}$ & $\begin{array}{c}\text { - Illegal fishing, also by deep } \\
\text { trawling that is really invasive (also } \\
\text { for archaeological structures) }\end{array}$ \\
\hline $\begin{array}{c}\text { - High presence of artificial and } \\
\text { natural coastal caves }\end{array}$ & - Difficulties in controlling \\
\hline
\end{tabular}

Table 1. Gaiola MPA Markers

The objective of this plan is to re-evaluate not only Posillipo but the Neapolitan territory in general, starting with the enhancement and the dissemination of its archaeological, historical and naturalistic heritage. This wealth has not been deployed enough although it can provide the opportunities for developing alternative touristic flows and work for young people interested in cultural development. The aim is to create in the area a centre for the dissemination of the "sustainable development" principles, starting from the new generation. This was done in September 2011 through the organization of a bilateral exchange between Italian and Bulgarian students on the theme of sustainable development in the MPA, thanks to the founding of the European Program "Youth in Action". Cleaning up the area and monitoring illicit actions gradually involving the local population are other important goals of the plan. This would increase the effectiveness and positive results through the creation of a "community spirit" around the park. So many young volunteers and voluntary associations are already involved in the cleaning up and the results of the prevention of 
illicit actions are disseminated to visitors that come to the MPA by showing pictures, videos and explaining the importance of the results. A fundamental action for the re-development of the area it has been the opening in 2010 of the new Research and Visitor Centre of the MPA (CeRD). The old Centre was set in an old building located at the entrance of the Integral Reserve Area. The building was a tangible sign of the area degradation and it was an obstacle for the real control of the A Zone of the MPA. For this reason the opening of the new centre helped the development of the research and tourist activities and nowadays it is the headquarters for the preservation and enhancement of the area.

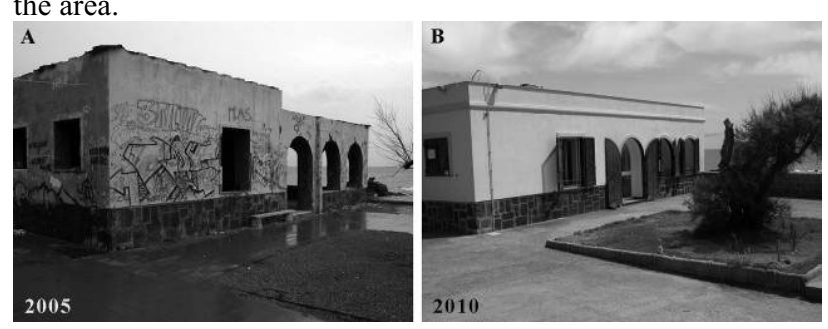

Figure 5 A) 2005 - Abandoned building in Zone A of the MPA; B) 2010 - Same building transformed in the Visitor and Research Centre of the Park.

\section{CONCLUSION}

In the last 10 years important results have been obtained in the Posillipo area, thanks to the collaboration between a government authority and an NGO active in the territory. There is no doubt that the strength of the development plan of the area lies in the interdisciplinary approach which makes it possible to cover all the fields of competence required in such a mixed environment. The results are positive and very promising, especially considering the particular anthropic pressure on the area and the environmental degradation conditions in which it was ten years ago. However, it is also necessary to underline how difficult and complicated it often is to manage the MPA, areas in which historical, archaeological, environmental and social features are mixed together. At the same time, these constituents are an important part of the Mediterranean Cultural and Environmental Heritage.

In the last two decades, thanks to the development of new technologies, the study of underwater remains and the environment has become possible, and it is for this reason that the Marine Protected Areas were gradually instituted all over the Mediterranean, and local institutions started to worry about how this common heritage could best be preserved. The problems to solve are many and varied, also from a legislative point of view. Proof of how interest in this new kind of venture has spread is the 2001 UNESCO Convention for the protection and the preservation of the Underwater Archaeological Heritage (Maniscalco, 2004). The 2001 Convention aimed to fix common rules to make up for the lack of laws regarding the preservation of the underwater heritage in many countries, and it is part of a bigger project named "Environment and Development in Coastal Regions and in Small Islands" which aims to recognize the preservation of the local maritime cultures and environments as an instrument of development. It is also important that citizens, the local population and visitors, become involved and make underwater archaeological sites their own in a sustainable way, especially to support their preservation (Pieroni \& Romita, 2003). This aspect is especially important in countries like Italy or Egypt where the archaeological heritage is particularly rich and, consequently, attention is usually focused only on the biggest and most prominent sites (in Southern Italy see the example of Pompei) leaving the smaller realities such as Marine Protected Areas without adequate institutional intervention. In fact, the first problem MPA faces is that the heritage is not immediately visible to most people, and so, of course, it is difficult to ascribe importance to it or to value it. Also, many people are not at ease in water and feel that what lies submerged has nothing to do with them, does not belong to them, but according to the 2001 Convention the preservation of underwater remains entails encouraging conservation of the remains in their original context; the remains have to be left underwater and a way must be found to allow people to "visit" and learn to appreciate them. As Rule 1 of the Convention states: The protection of the underwater archaeological heritage throughout in situ preservation shall be authorized in a manner consistent with the protection of that heritage, and subjected to that requirement may be authorized for the purpose of making a significant contribution to protection or knowledge or enhancement of underwater cultural heritage.

Because of the new interest in these particular sites ambitious projects have been undertaken such as the plan to build the Archaeological Underwater Museum in Alexandria literally underwater. In 2008 UNESCO decided to nominate a commission to evaluate the real possibility of realizing such a project. The work for the construction of the Museum was supposed to start in 2010, but so far nothing has been done. As the UNESCO commission underlined, the problem is that the project was too ambitious, also considering the fact that before the idea of building an underwater museum presented itself, nothing had actually been done to preserve the Egyptian underwater heritage all over the country (Morcos et al., 2003). The example of Alexandria demonstrates that in MPA management there is still a lot of basic and elementary work to do in many Mediterranean Countries, Italy included, even though some projects, like the VENUS one financed by the European Commission and carried out by different European countries are going in the right direction to study and preserve the underwater heritage in a non-invasive and sustainable way (Chapman et al., 2006).

The results presented in this paper are not the end of a work, but just the starting point for further research, aimed at analyzing the Mediterranean context, is now developing in order to create a model to analyze the new possibilities and way to manage the underwater heritage. The new challenge is now to better understand the original function of some underwater remains, and at the same time to develop a good system to preserve the Gaiola underwater remains, but at the same time let them be accessible to visitors. The help of new technologies will be fundamental in these new projects.

\section{References}

Anzidei, M. (et al.), 2005. Siti archeologici costieri di età romana come indicatori delle variazioni del livello del mare: un'applicazione al mare Tirreno (Italia centrale). L. De Maria \& R. Turchetti (Eds): Evolucion paleoambiental de los puertos y fondaderos andtiguos en el Mediterraneo occidental. Rubbettino, Rome, pp. 115-126.

Caputo, P., 2004. Beni archeologici sommersi nel territorio della Soprintendenza per $i$ Beni Archeologici di Napoli e Caserta: per un turismo archeologico subacqueo sostenibile. F. Maniscalco (Ed): Tutela, Conservazione e Valorizzazione del Patrimonio Culturale Subacqueo, pp. 203-209.

Chapman, P. (et al.), 2006. VENUS, Virtual exploration of underwater site. Proceedings of The 7th International 
Symposium on Virtual Reality, Archaeology and Cultural Heritage VAST.

Columella, L.G.M. De Re Rustica, Liber VIII.

D'Arms, J. H., 2003. Romans on the Bay of Naples and other essays on the Roman Campania. Edi Puglia, Bari.

Deino, A. L. (et al.), 2004. The age of the Neapolitan Yellow Tuff caldera-forming eruption (Campi Flegrei caldera - Italy) assessed by ${ }^{40} \mathrm{Ar} /{ }^{39} \mathrm{Ar}$ dating method. Journal of Volcanology and Geothermal Research, 133, pp.157-170.

Günther, R. T., 1903. Contribution to the study of EarthMovements in the Bay of Naples. Oxford, Parker \& Son ed.

Günther, R. T., 1913. Pausilypon. The Imperial Villa near Naples. Oxford University Press.

Jacono, L., 1913. Note di archeologia marittima. Neapolis ed, pp. 353-371.

Lambeck, K. (et al.), 2004. Sea level in Roman time in the Central Mediterranean and implications for recent change. Earth and Planetary Science Letters, 224, pp. 563-575.

Maniscalco, F., 2004. Beni archeologici sommersi nel territorio della Soprintendenza per $i$ Beni Archeologici di Napoli e Caserta: per un turismo archeologico subacqueo sostenibile. F. Maniscalco (Ed): Tutela, Conservazione e Valorizzazione del Patrimonio Culturale Subacqueo, pp. 91-112.

Marriner, N. \& Morhange, C. 2007. Geoscience of ancient Mediterranean harbours. Earth Science Review, 80, pp. 137194.

Morcos, S. (et al.), 2003. Towards Integrated Management of Alexandria's Coastal Heritage. A joint endeavour of the University of Alexandria, Supreme Council of Antiquities (Egypt), Governorate of Alexandria and UNESCO. http://www.unesco.org/csi/pub/papers2/alex.htm (accessed on 08 Feb. 2012).

Pagano, M., 1981. Gli impianti marittimi della Villa Pausilypon. In: Puteoli. Studi di storia antica, IV-V, pp. 245-255.

Pieroni, O. \& Romita, T., 2003. Viaggiare, conoscere $e$ rispettare l'ambiente, verso il turismo sostenibile. Rubettino ed.

Pirazzoli, P., 1976. Sea level variations in the northwest Mediterranean during roman times. Sciences, 194, pp. 519-521.

Rustico, L., 1999. Peschiere Romane. Mélanges de l'Ècole Française de Rome Antiqué, Tome 111 (1), pp. 51-66.

Schmiedt, G., 1972. Il livello antico del Mar Tirreno: testimonianze dei resti archeologici. L.S Olschki, Firenze.

Simeone, M. (et al.), 2008. Le Grotte di Trentaremi e le altre cavità costiere dell'Area Marina Protetta Parco Sommerso di Gaiola (Golfo di Napoli): aspetti geoarcheologici ed ecologici. Opera Ipogea, 1-2, pp. 307-314.

Simeone, M. (et al.), 2010. Relazione tecnica "Servizio ordinario di monitoraggio biologico-ambientale del Parco Sommerso di Gaiola" - Soprintendenza Speciale per I Beni
Archeologici di Napoli e Pompei - Centro Studi Interdisciplinari Gaiola Onlus. (Technical Report)

Simeone, M. \& Russo, G. F., 2005. Il Parco Sommerso della Gaiola. G. C. Carrada, P. Coiro., G. F. Russo (Eds). Le aree marine protette. I Quaderni di Uomo e Natura $n^{\circ} 2$. Electa ed., Napoli, pp. 85-94.

Simeone, M. \& Masucci, P. 2009. Analisi geo-archeologiche nell'Area Marina Protetta Parco Sommerso di Gaiola (Golfo di Napoli). Il Quaternario - Italian Journal of Quaternary Sciences, 22, pp. 25-32.

Vecchio, G., 1999. La Grotta di Seiano e il Parco Archeologico del Pausilypon”. Il Mattino, Electa ed. 